\title{
The Influence of Hydrophobicity Factor on Wool Fibre Dyeing With Anionic Dye
}

\author{
Rasa TREIGIENE $\dot{1}^{1 *}$, Juozas MUSNICKAS $^{2}$, Lina RAGELIENE $^{3}$ \\ ${ }^{1}$ Department of Textile Technology, Kaunas University of Technology, Studentu 56, LT-51424 Kaunas, Lithuania \\ ${ }^{2}$ Department of Organic Technology, Kaunas University of Technology, Radvilenu 19, LT-50254 Kaunas, Lithuania \\ ${ }^{3}$ Department of Biochemistry and Biotechnologies, Vytautas Magnus University, Vileikos 8, LT-44404 Kaunas, Lithuania \\ crossref $\mathrm{http}: / / \mathrm{dx}$.doi.org/10.5755/j01.ms.17.3.596
}

Received 20 September 2010; accepted 17 January 2011

\begin{abstract}
In this study two alkylphenolethoxylates with different ethoxylation degree c.a. EO 9 (Lanasan LT as NPE-1) and EO 40 (Disponil AA P43 as NPE-2) were selected with the purpose to evaluate the influence of hydrophobicity of nonionic surfactants on wool dyeing efficiency. Anionic C.I. Acid Orange 7 dye was used to carry out an experiment in dyeing of wool fibre at $30^{\circ} \mathrm{C}$ or $60^{\circ} \mathrm{C}$ temperature using wool fabric which was prepared for dyeing by extraction of the lipid materials soluble in chloroform and methanol mixture. The surfactant with a shorter hydrophilic chain (NPE-1) intensified the adsorption of the dye. This fact allowed to presume that the dye diffusion into wool fibre might be influenced by hydrophobic interaction between the surfactant and hydrophobic sites of wool fibre. The results of surfactants adsorption showed that the interaction of NPE-2 with the fibre was weak as compared to that of NPE-1. The results of the investigation suggest that the ethoxylated nonylphenol of a lower hydrophility index might interact with the active sites of wool fibre more intensively than that of a higher index of hydrophility.
\end{abstract}

Keywords: dyeing, surfactant, wool.

\section{INTRODUCTION}

Early workers studying the uptake of dyes by wool were mainly interested in the thermodynamics of the dyeing process $[1,2]$. Those approaches, which treated the wool fibre as a cylinder of uniform composition, were largely concerned with the application of situation when dyebath equilibrium had been attained. They provided little information on the mechanism of the dyeing process itself, however [2].

Over the past four decades there has been a growing recognition of the importance of the diverse morphological structure of wool in determining its dyeing behaviour. When a textile substrate is dyed by an exhaustion method, the dyeing operation proceeds in the stages $[1,2]$ :

- diffusion of dye through the aqueous dyebath to the fibre surface;

- transfer of dye across the fibre surface;

- diffusion of the dye from the surface throughout the whole fibre.

When a textile fibre is immersed in a solution, there is a spontaneous transfer of dye from the solution to the fibre phase resulting in reduction of concentration in the solution. This is because the movement of dye between the phases results in the system reaching a state of lower energy or higher stability [3].

The factors considered, which in a certain way influence the value of the coefficient of dye diffusion and, therefore, determine the rate of dyeing fibres, are the molecular size, affinity, the presence of aggregates, the interaction between all the chemical species present in both phases, as well as the temperature and changes in the physical structure of the substrate [4].

The cell membrane complex with hydrophobic lipid components and easily swollen intercellular cement

\footnotetext{
*Corresponding author. Tel.: +370-37-300220; fax.: +370-37-353989. E-mail address: rasa.treigiene@ktu.lt (R. Treigienè)
}

consisting of lightly crosslinked nonkeratinous protein is believed to provide pathways for diffusion of reagents into wool $[2,5]$. The findings of other research works [6], which examined absorption of nanoparticles by wool, supported the view that cell membrane complex and other sulphur regions are the main route of entry for both molecular and macromolecular treatment chemicals. There were some papers [2,7-12] which showed that nonkeratinous regions of wool fibre could be modified by enzymes, polar organic solvents, anhydrous alkali, nonionic or amphoteric surfactants which are used in wool fibre treatments. Subsequently, the dyeing rate of wool fibre could significantly increase.

Although detailed knowledge of dyeing mechanisms has been accumulated over the years, substantial gaps in that knowledge still remain [1].

Investigations of the influence of nonionic surfactants on the process of wool fibre dyeing with anionic dyes are important in theoretical and practical approaches [12]. Topicality of such investigations in dyeing of protein fibre is growing up in terms of improvement of dye diffusion and its distribution equality in fibre or diminution of fibre destruction running in this process [13].

The pre-treatment of wool with commercial non-ionic products incorporating both short-chain etoxylated alkylnonylphenols and longer-chain dispersing agents Lanasan LT (Clariant) or Baylan NT (Bayer) has caused an increase in total dye absorption into fibre and increase in the dyeing rate, when the temperature of the dyeing liquor was $85^{\circ} \mathrm{C}[9]$.

L. Coderch [10] et al. concluded that Baylan NT could modify the hydrophobic domains of the cell membrane complex (CMC) of wool fibre as well as form an auxiliary/dye complex. These two reasons may favour dye diffusion into fibre at a low temperature.

Nonionic alkylphenolethoxylate type surfactants are known as adducts forming complexes with wool fibre by 
means of hydrophobic interactions between hydrophobic sites [14].

Nonionic auxiliary in the dyebath renders a reduction of surface barrier to the dye diffusion into the fiber. Nonionic nonylphenol ethoxylate used as a dyeing auxiliary tends to be strongly adsorbed and, moreover, more readily than the dye in the inner layers of wool fibre. It could be that nonionic auxiliary exerts blocking of hydrophobic sites of fibre and thus prevents the immobilization of dye in the initial stage of dyeing [15].

The offer of nonionic surfactants for wool fibre treatments increases; however, the mechanism by which a nonionic surfactant improves the dyeing ability of wool fibre is not known yet and some published papers announce their hypotheses.

The objective of this study was to evaluate the influence of hydrophobicity of nonionic surfactants on the dyeing efficiency of wool fibre.

\section{EXPERIMENTAL}

\subsection{Materials}

Wool fabric. The fabric of pure merino wool complying with the regulations of ISO 105/F-1985 (E) standard was used in this work. Such fabric was called as standard fabric.

Dye. Wool fabric samples were dyed in the aqueous solutions of C.I. Acid Orange 7 (Sigma Co). Molecular weight of the dye was 350 and purity was $98 \%$ (1).

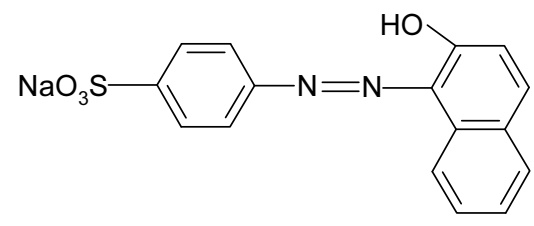

Surfactants. Two nonionic alkylphenolethoxylates (2): Lanasan LT (Clariant) and Disponil AA P43 (CHT) were used in the investigation. These two alkylphenolethoxylates differed in the amount of ethoxy groups in the molecule and in their hydrophilic-lipophilic balance (HLB), which was 12.8 for Lanasan LT (NPE-1) and 17.9 for Disponil AA P43 (NPE-2).

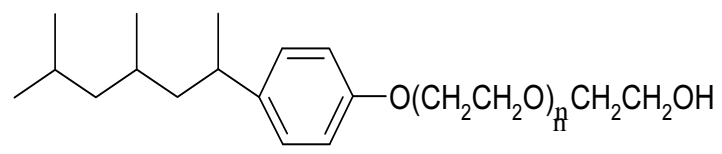

The mean of $n$, i.e. the ethoxy group number, in formula (2) is 9 for NPE-1 and 40 for NPE-2.

\subsection{Procedures}

Fabric treatments. Standard wool fabric samples were extracted with chloroform/methanol mixture in Soxhlet extractor. Extraction lasted 10 overfills.

Dyeing. The samples of extracted wool fabric were dyed under such dyeing conditions: $5 \times 10^{-3} \mathrm{~mol} / \mathrm{l}$ of C.I. Acid Orange $7,1.5 \times 10^{-4} \mathrm{~mol} / \mathrm{l}$ of Lanasan LT or $2.3 \times 10^{-4}$ mol/l Disponil AA P43, M 500, pH 4.2, dyeing temperatures $30^{\circ} \mathrm{C}$ and $60^{\circ} \mathrm{C}$. Wool samples were dyed in the laboratory apparatus.

Treatment with surfactants. Extracted and standard wool fabrics were treated in aqueous solutions of $1.5 \times 10^{-4}$ $\mathrm{mol} / 1 \mathrm{NPE}-1$ or $2.3 \times 10^{-4} \mathrm{~mol} / 1 \mathrm{NPE}-2$ at $30^{\circ} \mathrm{C}$ and $60^{\circ} \mathrm{C}$ temperatures; when the bath modulus was M 100, treatment time $75 \mathrm{~min}$, stirring was used. Samples were soaked in a buffer solution of $\mathrm{pH}$ 4.2. The excess of solution was removed before subsequent wool treatment in surfactant solution. The concentrations of NPE-1 and NPE-2 were chosen in agreement with the results of surface tension variations subject to concentrations of NPE-1 and NPE-2 in aqueous solution. Turbidity of NPE-1 aqueous solutions was observed at the concentration $7.5 \times 10^{-4} \mathrm{~mol} / \mathrm{l}$ and above. The results of investigation of optical density against NPE-1 concentration from $1 \mathrm{~mol} / 1$ to $6 \times 10^{-4} \mathrm{~mol} / 1$ and NPE-2 concentration from $0.5 \mathrm{~mol} / 1$ to $12 \times 10^{-4} \mathrm{~mol} / \mathrm{l}$ in aqueous solutions showed strong dependence $\left(R^{2}\right.$ was 0.999 for both). Solutions of mentioned concentrations were without turbidity. Accordingly, the results of the concentrations of surfactant solutions used in this investigation were lower than the concentrations of their aggregate formation.

\subsection{Tests}

Dye or surfactant uptake by wool from aqueous solution was analysed using Spectronic Unicom Genesys TM 8 device. The concentrations of surfactants and dye in the solutions were estimated by measuring their absorbance at absorbance wavelength $277 \mathrm{~nm}$ and $488 \mathrm{~nm}$ respectively.

\section{RESULTS AND DISCUSSION}

\subsection{The influence of temperature and surfactant on the acidic dye sorption into wool fibre}

Wool fabric samples were prepared for the dyeing experiment by processing them with chloroform/methanol mixture in order to extract and remove the surface bound lipids and a part of fatty acids of lipids from the wool cell membrane complex [16-18]. It is known that the nature of wool fibre surface significantly influences the adsorption of chemicals [2] and of nonionic surfactant [19] as well, as the structure of cell membrane complex influences the diffusion of reagents from the surface throughout the whole fibre [2]. The lipid barrier located at and near the wool surface was removed. The samples of extracted wool fibre were dyed in the solutions of C.I. Acid Orange 7 dye without surfactant, with additive of NPE-1 or NPE-2 at $30^{\circ} \mathrm{C}$. Kinetic curves presented in Fig. 1 demonstrate low intensity of wool fibre dyeing rate when the surfactant with longer hydrophilic chain NPE-2 was added to the dyeing solution, and it is close to the results received when the dyeing process was carried out without the surfactant. The different results were obtained when the surfactant with shorter hydrophilic chain and lower ethoxylation degree NPE-1 was used in the dyeing solution. Amount of absorbed C.I. Acid Orange 7 dye into wool and intensity of dyeing were higher compared to those of dyeings with NPE-2 additive in the dye solution.

Wool fibre dyeing treatments at $60{ }^{\circ} \mathrm{C}$ (Fig. 2) showed the opposite effect of NPE-2 to acid dye sorption into wool fibre comparing with the effect of NPE-1. More hydrophilic surfactant NPE-2 reduced the sorption of C.I. Acid Orange 7 dye into the wool fibre. At the same dyeing time 
wool fibres dyed in the solution without surfactant or with NPE-1 absorbed more dye than wool fibre dyed in the solution with NPE-2.

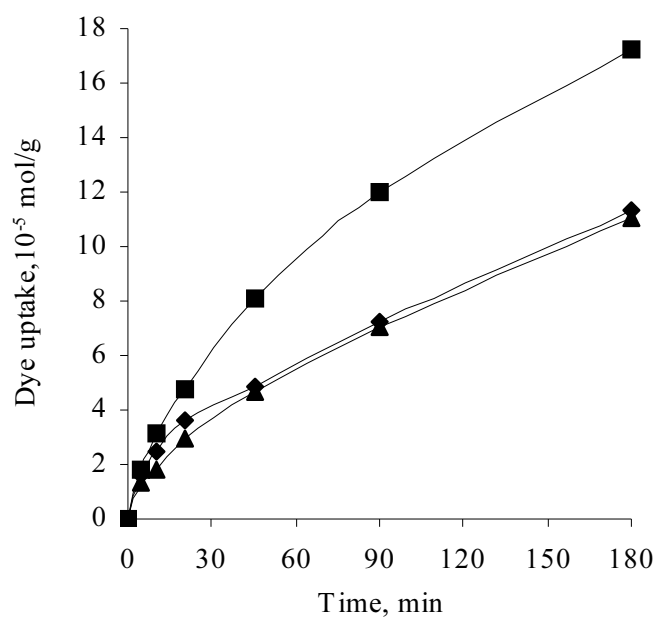

Fig. 1. Kinetic curves of C.I. Acid Orange 7 dye sorption onto extracted wool fibre at $30^{\circ} \mathrm{C}$. Dyeing without surfactant $(\bullet)$, with NPE-1 $(\boldsymbol{\square})$, with NPE-2 ( $\mathbf{A})$

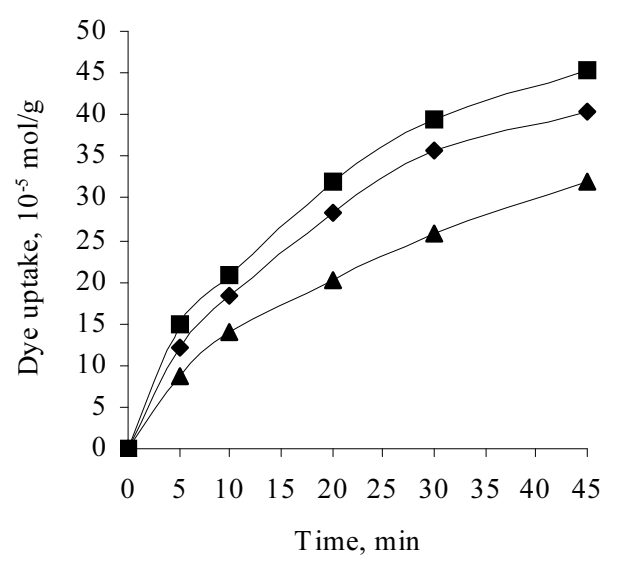

Fig. 2. Kinetic curves of C.I. Acid Orange 7 dye sorption onto extracted wool fibre at $60^{\circ} \mathrm{C}$. Dyeing without surfactant

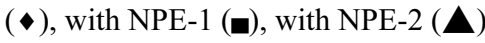

Different influence of nonionic surfactant NPE-2 and NPE-1 on intensity of C.I. Acid Orange 7 dye sorption into wool fibre may be explained by their different hydrophobicity and ability to make hydrophobic interaction with wool fibre. Since NPE-1 was more hydrophobic compared to NPE-2, therefore hydrophobic interaction between hydrophobic groups of wool fibre and surfactant of the kind could be more expressed. Therefore, the fibre was hydrophilised more, which enabled the penetration of higher quantity of acid dye into the deeper layers of wool fibre. For the same reason, the acid dye sorption into wool fibre was more intensive when NPE-1 was added to the dye solution.

\subsection{The influence of surfactant hydrophobicity on the sorption into wool fibre}

Uptake of nonionic surfactants NPE-1 and NPE-2 into wool fibre was determined as well. Samples of wool fibres were treated in aqueous solutions of NPE-1 or NPE-2 at 30 and $60{ }^{\circ} \mathrm{C}$ temperatures.
Kinetic curves of NPE-1 sorption into wool fibre are presented in Fig. 3. The results of investigation showed that extraction of wool fibre with chloroform/methanol mixture did not influence the rate and amount of surfactant sorption into wool, as $30^{\circ} \mathrm{C}$ kinetic curves were almost identical. This could be explained by the fact that internal wool lipids soluble in organic solvents had no substantial influence on penetration of NPE-1 into the wool fibre when the temperature was $30^{\circ} \mathrm{C}$. The increase of surfactant solution temperature from $30^{\circ} \mathrm{C}$ to $60^{\circ} \mathrm{C}$ increased NPE-1 equilibrium sorption to $9.5 \times 10^{-6} \mathrm{~mol} / \mathrm{g}$. Our results of investigation are very close to the results published in the literature [20], which had announced that the concentration of saturation of active wool centres by alkylnonylethoxylate may be reached up to $11 \times 10^{-6} \mathrm{~mol} / \mathrm{g}$.

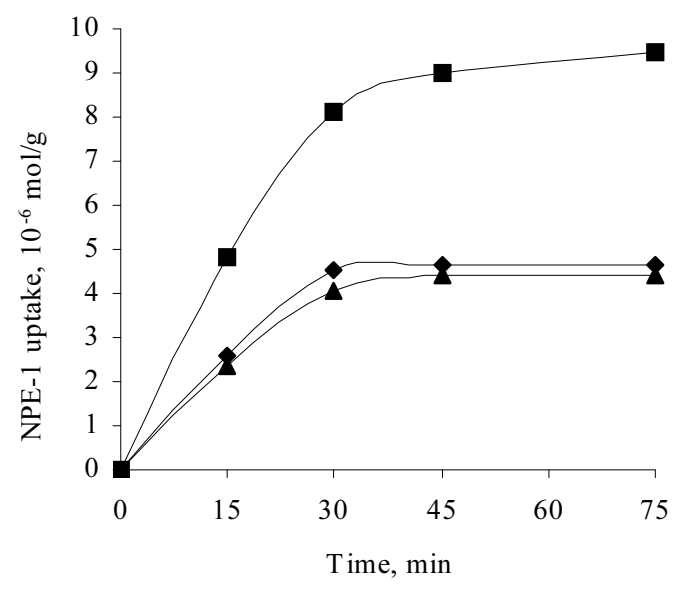

Fig. 3. Kinetic curves of NPE-1 sorption into wool fibre when standard $(\mathbf{\Delta})$ and extracted $(\bullet)$ wools were treated at $30{ }^{\circ} \mathrm{C}$; standard wool fibre $(\boldsymbol{\square})$ was treated at $60^{\circ} \mathrm{C}$

The results of investigation presented in Table 1 show that when the value of hydrophilic-lipophilic balance of nonionicethoxylate NPE-2 was higher (17.9), the absorption into wool fibre was standstilled.

Table 1. Optical densities of NPE-2 aqueous solutions at $30^{\circ} \mathrm{C}$

\begin{tabular}{|c|c|c|c|c|}
\hline \multirow{2}{*}{$\begin{array}{c}\text { Treatment } \\
\text { time, min }\end{array}$} & \multicolumn{2}{|c|}{ Standard wool } & \multicolumn{2}{c|}{ Extracted wool } \\
\cline { 2 - 5 } & $\begin{array}{c}\text { Optical } \\
\text { density }\end{array}$ & $\begin{array}{c}\mathrm{pH} \text { of } \\
\text { solution }\end{array}$ & $\begin{array}{c}\text { Optical } \\
\text { density }\end{array}$ & $\begin{array}{c}\mathrm{pH} \text { of } \\
\text { solution }\end{array}$ \\
\hline 0 & 0.267 & 4.20 & 0.283 & 5.25 \\
\hline 15 & 0.274 & 4.22 & 0.335 & 6.40 \\
\hline 30 & 0.273 & 4.20 & - & - \\
\hline 45 & 0.276 & 4.27 & - & - \\
\hline 60 & 0.284 & 4.23 & 0.335 & 6.44 \\
\hline
\end{tabular}

Optical densities of NPE-2 aqueous solutions, herewith the concentration of NPE-2, have not decreased; on the contrary, they have increased. This is opposite to that case when wool fibre was treated in NPE-1 aqueous solution. The increase of optical densities in solutions might be related to the migration of wool proteins possessing a phenyl ring in the solution used.

According to the literature [13] though wool fibre was treated under the mild conditions in cold water, the proteins soluble in water medium pulled away. 


\section{CONCLUSIONS}

The higher intensity of C.I. Acid Orange 7 dye sorption into wool fibre from solution containing nonionic alkylphenolethoxylate NPE-1 (HLB 12.8) compared to alkylphenolethoxylate NPE-2 (HLB 17.9) can be explained by the more hydrophobic character of NPE-1 and its ability to form hydrophobic interaction with wool fibre.

\section{REFERENCES}

1. Park, J., Shore, J. Does Dyeing Practice Need Dyeing Theory? Coloration Technology 123 2007: pp. 339-343.

2. Lewis, D. M. Wool Dyeing. Bradford, UK, 1992: 372 p.

3. Car, C. M. Chemistry of the Textile Industry. Cambridge, Great Britain, 1995: 361 p.

4. Cegara, J., Valdepperas, J. The Dyeing of Textile Materials. Torino, Italy, 1992: 703 p.

5. Harrigan, F., J., Rippon, J, A. New Method for Dyeing Wool at Low Temperature Proceedings of Textile Institute World Conference Sydney, 1988: pp. 412-419.

6. King, D., Pierlot, A. Absortion of Nanoparticles by Wool Coloration Technology 125 2009: pp. 111-116.

7. Riva, A., Alsina, J. M., Rrieto, R. Enzymes as Auxiliary Agents in Wool Dyeing Journal of the Society Dyers and Colorists 115 1999: pp. 125-129.

8. El-Sayed, W., Nofal, R., El-Sayed, H. Use of Lipoprotein Lipase in the Improvement of Some Properties of Wool Fabrics Coloration Technology 126 2010: pp. 296-302.

9. Riva, A., Cegara, J. Sorption of Nonionic Auxiliary Products by Wool Its Influence on Dyeing with Acid Dyes Journal of Society Dyers and Colorists 112 1996: pp. $114-116$.

10. Coderch, L., Lopez, O., De la Maza, Manich, A. M., Parra, J. L., Cegara, J. Internal Lipid Wool Structure Modification Due to a Nonionic Auxiliary Used in Dyeing at
Low Temperatures Textile Research Journal 67 (2) 1997: pp. $131-136$.

11. Treigienė, R, Budreikienè, G., Kaminskaitè, R., Musnickas, J. The Effect of Fibre Activative or Protective Agents on Physical Properties of Low Temperature Dyed Wool Fabric Materials Science (Medžiagotyra) 6 (3) 2000: pp. $221-225$.

12. Marti, M., Ramirez, R., Barba, Cl., Coderch, L., Parra, J. Influence of Internal Lipid on Dyeing of Wool Fibers Textile Research Journal 80 2010: pp. 365-373.

13. Lewis, D. M. Damage in Wool Dyeing Review of Progress in Coloration 19 1989: pp. 49-55.

14. Schenfeld, N. Grenzflachenaktive Athylenoxid-Addukte. Stuttgart, 1976: $750 \mathrm{p}$.

15. Musnickas, J., Kantautas, J., Rupainytė, V., Treigienė, R. Influence of Morphological Heterogenity of Wool Fibre on Acid Dye Sorption Level Materials Science (Medžiagotyra) 10 (4) 2004: pp. 359-362.

16. Knott, J. The Determination of Extractable Matter in Scoured Wool Tops Proceedings of the $8^{\text {th }}$ International Wool Textile Research Conference New Zeland 2 1990: pp. $209-217$.

17. Leeder, J. D., Bishop, D. G., Jones, L. N. Internal Lipids of Wool Fibers Textile Research Journal 7 1983: pp. $402-407$.

18. Korner, A., Hocker, H., Rivett, D. The Fatty-acids Composition of Lipids from Wool Cell-membrane Complex Journal of Analytical Chemistry 11 1992: pp. 501-509.

19. Brack, N. Nonionic Surfactants and the Wool Fibre Surface Colloids and Surfaces 146 1999: pp. 405-415.

20. Schenfeld, N. Surfactants on Ethylenoxide Base. Moscow, 1982: 376 p. (in Russian).

Presented at the International Conference

"Baltic Polymer Symposium'2010"

(Palanga, Lithuania, September 8-11, 2010) 